\title{
Porque palabras duelen más que puñadas. La injuria en Nueva España, siglos XVI y XVII
}

\author{
Rodrigo Salomón Pérez \\ Universidad Nacional Autónoma de México \\ epogesis@hotmail.com
}

\begin{abstract}
Resumen
En la Nueva España de los siglos XVI y XVII, el ataque a la honra personal por medio de injurias era suficiente motivo para entablar un juicio criminal; se manifestaba con esta noción la importancia social de tales ofensas. En el presente artículo se analiza la injuria, así como las representaciones que la tramaban, a partir de la información consignada en las distintas causas criminales levantadas por las instituciones a cargo de perseguir y sancionar el delito de injuria.
\end{abstract}

Palabras clave: Nueva España, siglos XVI y XVII, injuria, honra.

\begin{abstract}
In 16th and 17th century in New Spain, the assault to the personal honor by means of slander was an acceptable cause for beginning a criminal trial. Therefore, it was a social concern about such offenses. In this current article, slander is analyzed, as well as its mental representations. They are reviewed as a result of the information recorded by Institutions which conducted and penalized all suits in several crime causes for injuries.
\end{abstract}

Key words: New Spain, 16th and 17th centuries, slander, honor.

La historiografía contemporánea ha descubierto la importancia de las palabras habladas en el pasado y ha explorado las formas como el lenguaje refleja determinados contextos sociales. El estudio de las formas de comunicación oral presentes en diversas fuentes - expedientes de índole judicial, matrimonial o eclesiástica, correspondencia privada, memorias, diarios personales, etcétera - ha permitido observar que la dinámica del lenguaje nos remite a una dinámica social específica, pues las palabras no son pura sustancia lingüística que se mueve de forma autónoma de una realidad concreta, sino elementos constitutivos y constituyentes de ella. Las abstractas relaciones de género, posición y jerarquía social adquieren forma concreta en los actos y conversaciones triviales que los hombres y las mu- 
jeres del pasado establecían en las calles, mercados, plazas y vecindades, espacios donde la mayoría de la población platicaba sobre sus experiencias y visiones del mundo y de la sociedad en la que vivían. Estas impresiones que se hallan en las fuentes documentales permiten, de forma implícita o explicita, observar al historiador que los distintos órdenes sociales del pasado, lejos de permanecer estáticos, estaban en continuo cambio y dinamismo.

Las formas de comunicación oral en las que los historiadores han puesto mayor interés, son aquellas que tendían a alterar el orden social (Garrioch, Burke, Martin, Lipsset-Rivera, Madero, Millán) ${ }^{1}$, pues los denuestos presentes en mitad de triviales riñas y pleitos permiten establecer valiosas pistas para comprender los valores de una sociedad. Todas las expresiones vertidas en un conflicto semejante remiten a los valores e imaginarios ${ }^{2}$ sociales que pervivían y se respiraban en una época y comunidad dadas. En las sociedades regidas por el concepto del honor, como lo fue la novohispana, el ataque a la reputación personal por medio de palabras podía servir perfectamente para desencadenar una secuencia de acciones violentas, tendientes a responder la ofensa recibida, o establecer juicios criminales en contra de los ofensores, con lo cual se manifestaba la importancia social de tales palabras. Así, en el presente trabajo se analiza una de esas expresiones ofensivas, la injuria, y las representaciones que la tramaban, a partir de la información consignada en las distintas causas criminales levantadas por algunas de las instituciones encargadas de perseguir y sancionar el delito de injuria, tales como la justicia eclesiástica, encabezada por el Vicario General y Provisor Oficial del arzobispado de México (Trasloheros Hernández 37-41); las justicias reales, representadas por los Alcaldes Mayores y los Corregidores, en su papel de jueces de lo criminal (González y Lozano, "El alcalde" 568 y "La administración" 83), y el Tribunal del Santo Oficio de la Inquisición, facultado para seguir los procesos de orden criminal en contra o interpuestos por sus integrantes.

Proveniente etimológicamente de la voz latina iniuria, la injuria es definida en un diccionario de la época como un "hecho ú dicho contra razón, ó contra lo que debe ser, especialmente contra justicia por el daño que se sigue a otro. Vale [también] lo que se hace contra derecho" (Covarrubias y Orozco, "Injuria" 670). Para Tomás de Mercado, maestro de Teología en el Convento de Santo Domingo de la

Antonio Millán señala interesantes posibilidades de estudio en torno a los insultos y sugiere novedosas perspectivas de estudio interdisciplinario entre la lingüística, la antropología y la historia.

2 El término imaginario en este trabajo será entendido como la definición que ofrece La Nouvelle Histoire: "El campo de lo imaginario está constituido por el conjunto de representaciones que desbordan el límite trazado por los testimonios de la experiencia y los encadenamientos deductivos que ellos autorizan" (Patlagean 249). 
Ciudad de México, era una palabra o acción que pretendía "cortar y trazar la fama del vecino, no para predicar lo bueno que en él hay, sino para exagerar el mal y aun para fingirlo..." (Mercado vol. 2, 598). Y Las Siete Partidas, código medieval de gran influencia en el derecho procesal indiano, la definía como una "deshonra que es fecha o dicha a otro a tuerto (Covarrubias y Orozco, "Tuerto" 981) o a despreciamiento del" (Alfonso X el Sabio, partida VII, título IX, ley I, 574).

Desde una perspectiva social, la injuria era una puesta en escena en la que, a partir de un guión estructurado por códigos y costumbres sociales, sus protagonistas actuaban y enunciaban argumentos con el propósito de atentar contra la honra de alguien. Con esa intención, el injuriador construía y emitía las expresiones adecuadas para tal propósito, y el injuriado, ante tal circunstancia, decidía o asumirse como ofendido o disimular, si podía, la ofensa lanzada. Los testigos, por su parte, se erigían en componentes trascendentes de la trama, pues sin ellos, sin esa audiencia expectante que calculaba y medía el mensaje emitido, al mismo tiempo que la reacción del receptor, una injuria poco o nada tendría de eficaz. Todo se efectuaba no en un escenario creado, sino en los espacios donde transcurría la cotidianeidad: la calle, la plaza, la pulpería, el mercado o la propia vecindad. De esa manera, se establecía un sistema que relacionaba de forma sincrónica a todos los componentes de la representación en un sentido y en un espacio dados.

En el acto injurioso existían tres momentos: la emisión de un mensaje o la realización de una acción, en cuyo sustrato se hallaban intenciones injuriosas; la recepción de ese mensaje o acto, que invariablemente implicaba una interpretación, y la posterior reacción del injuriado, tendiente a reivindicar su honra maltrecha, fuese a través de un acto violento o recurriendo a las instituciones de justicia. Este proceso era consignado en los procesos criminales correspondientes, donde a la voluntad dolosa de injuriar alguien se le denominaba animo Iniuriandi. Retomado del Derecho Romano, dicho concepto manifiesta cualquiera de las motivaciones criminales aducidas por las autoridades, los agresores, las víctimas y los testigos, las cuales no pueden ser tomadas como objetivas, sino como indicios de los impulsos que llevaron a los inculpados a cometer delitos. Así, se acepta como motivo de una injuria el marco dentro del cual se cometió o la causa que la precipitó, pues las razones que hacían valer injuriados e injuriadores en una causa criminal nos permiten atisbar cómo interpretaban la situación y qué esperaban fuera propio y adecuado de la conducta social en el mundo novohispano, pero no debe confundirse con las razones psíquicas de la acción, que, en general, no pueden conocerse.

El 1 de junio de 1700 Vicente Francisco Pardo, mulato, vecino de la Ciudad de México, se querelló criminalmente contra Diego Vela, notario y ministro del Tribunal del Santo Oficio de la Santa Inquisición, por haber injuriado a su esposa, 
Juliana de San Juan de Dios, a quien llamó "grandísima puta", y a él, "cabrón cornudo", para después herirlo con su espada cerca de la ceja izquierda. Los hechos se suscitaron en la vecindad llamada De Los Cordobanes, cuando Vela acudió a la vivienda de Juliana para pedirle que callara a sus hijos, pues hacían mucho bullicio. Ella le explicó que le era imposible hacerlo porque eran niños, por lo que el quejoso regresó a su habitación, salió de ella con una espada en la mano - al parecer, para darles de cintarazos a los infantes - y tornó a la casa del matrimonio. Mientras discutía con Juliana, Vicente llegó y preguntó qué ocurría, el ministro le explicó la situación y amenazó con ir a querellarse por el perjuicio que hacían los niños. Pardo, molesto, le respondió “...que fuese a donde decía que se había de ir..." (AGN, I, vol. 75, expediente 3 , f. 1) y Vela reaccionó injuriándolo.

Tres meses después, el 16 de septiembre de 1700, un conflicto semejante tuvo como protagonistas a dos miembros del estamento eclesiástico, y como escenario, la casa del doctor Andrés Moreno, promotor fiscal del Arzobispado de México. Ocurrió que mientras este escribía algunas cartas en la sala principal de su casa, se presentó el licenciado Luis de Almaraz Carvajal, presbítero en el mismo Arzobispado de México, para reclamarle al doctor Moreno la construcción de unos mechinales, ordenada por Gabriel de Mendieta, uno de sus secretarios, sobre una pared que se encontraba en disputa, pues tanto Moreno como Almaraz reclamaban su propiedad. Este, de forma intempestiva, entró a la sala y con "voces desentonadas" le exigió al promotor que ordenara parar las obras; el doctor le pidió se contuviera y no le gritara, a lo que Almaraz le respondió que no quería controlarse, que la cólera le hacía hablar así, a lo que el promotor respondió que "mirase lo que decía", y, levantándose de su asiento, "le dijo al dicho presbítero Luis de Almaraz que no son cóleras a el aire [sino] a su persona [y] que va de corazón a corazón... y el dicho promotor le dijo se saliese y fuese con Dios y no venga aquí a gritar" (AGN, RFI, vol. 705, expediente 38, ff. 3-3v).

Acto seguido, Almaraz se retiró furioso, pero, justo cuando caminaba sobre el corredor que daba a la calle, se topó con una hermana y un primo del promotor, y se dio un nuevo altercado. Injurió a ella al tratarla de "puta" y los amenazó a ambos con un cuchillo. El brete terminó cuando otro vecino, Nicolás de Navarrete, acudió a la casa del promotor, luego de escuchar los "gritos y altas voces", logró desarmar a Almaraz y, a empellones, lo echó de la casa (AGN, RFI, vol. 705, expediente 38, ff. 3-3v).

En un ambiente en el que hombres y mujeres vivían casi "frente a frente", tal como ocurría en las ciudades y pueblos novohispanos del siglo XVII, era difícil para alguien que evitara escuchar y ver lo que ocurría en el entorno. Y era, precisamente, esa cercanía la que provocaba el surgimiento de injurias como las aquí referidas. Ante el escándalo y el bullicio provocados por los hijos de Vicente 
Francisco y Juliana, hecho tan cotidiano en los espacios habitacionales aglomerados, Vela reaccionó de forma intempestiva injuriándolos y golpeándolo a él, mientras que en el segundo caso un problema vecinal terminó violentamente y en mitad de un juicio criminal.

No sabremos las intenciones exactas que movieron al funcionario inquisitorial Diego Vela y al licenciado Luis de Almaraz Carvajal a injuriar a sus respectivas víctimas: la información vertida en las fuentes no permite conocer más. En cambio, podemos suponer que el animo iniuriandi que los motivó estuvo impulsado por un ambiente social hostil, donde la exasperación y el enojo fueron los factores causantes. Estas razones pueden extenderse a la mayoría de los procesos criminales por injurias entabladas en las instituciones judiciales novohispanas aquí revisadas. Pleitos vecinales (AGN, RFI, vol. 705, expediente 38, ff. 3-3v), discusiones entre arrendatarios e inquilinos (AGN, RFI, vol. 705, expediente 38, ff. 3-3v), conflictos por motivo de deudas (AGN, I, vol. 79, expediente 8, f. 10v), discusiones entre amigos que de pronto se salían de los cauces y desembocaban en riñas (AGN, I, vol. 79, expediente $8, f .10 \mathrm{v}$ ), reacciones ante abusos de autoridad (AGN, C, vol. 1, expediente 27, f. 14), o por la intromisión de terceras personas en conflictos ajenos (AGN, C, vol. 54, expediente 13, f. 4), o por desacuerdos en los tratos y negocios (AGN, T, vol. 2778, expediente 1, f. 2v)... en todas aquellos casos existía la constante de que las injurias prorrumpidas funcionaron más como reacciones de coraje y enojo que como actos premeditados con intenciones dolosas. En cambio, existían casos que se tornaban distintos porque había otros elementos para considerar, como lo ocurrido al encomendero Martín Cerón de Valdez cuando el sacerdote Martín Enríquez Cantú se dedicó a injuriarlo, al difundir las especie de que su abuelo y padre fueron "judios y descendientes de tales..." (AGN, C, vol. 611, expediente 4, f. 2v). Para probar su denuncia, el ofendido presentó como testigo, en primer lugar, al español Joseph de Suárez, quien declaró que desde hacía algún tiempo había escuchado algunos rumores sobre las injurias dichas por el cura hacia la persona de Martín Cerón; sin embargo, en una ocasión en que el padre Enríquez Cantú regresaba de oficiar misa del pueblo de Tecatepec, el testigo lo alcanzó a medio camino, y en mitad de la plática el presbítero le confío que Martín Cerón era un judío, así como todo su linaje. Suárez asentó que, indignado, le reconvino al cura por su dicho, pues él, como mucha gente, sabía de la notoria honradez e hidalguía de la familia Cerón Valdez. Enríquez, según Suárez, reafirmó sus aseveraciones, y para sustentarlas le contó la siguiente historia: el sacerdote refirió que Lucas de Paredes, padre de Martín Cerón de Valdés, antes de que se casara con doña María Cerón de Valdés, madre del ofendido, vivió largo tiempo en la región de la Huasteca. En una ocasión en que conversaba con algunos conocidos suyos, se acercó a la tertulia el arriero Fulano Hermosillo. Paredes se incomodó con su presencia y comentó: 
...señor Hermosillo no entenderá la conversación que estamos tratando yo y el señor Jiménez más bien entenderá de cuantas varas de jerga entran en un palmo [a lo cual, Hermosillo respondió:] (...) señor Lucas de Paredes yo muy bien entiendo las varas de jerga que entran en una palma porque soy arriero y tengo dos recuas mías muy buenas pero señor Lucas Paredes muy bien y mejor entenderá las varas de palio que entran en un San Benito... (AGN, C, vol. 611 , expediente 4, f. $2 \mathrm{v}$ )

Acto seguido, ambos hombres se "asieron de palabras", y en mitad de la reyerta Hermosillo insultó a Paredes diciéndole que era un "hereje judío" probado y que se lo habría de demostrar. Pasado el tiempo, narra Enríquez, el arriero exhibió ante muchas personas un testimonio que evidenciaba la calidad de converso de Paredes y las pruebas del castigo que había recibido. Documentos que en el momento de la querella, según el injuriador, guardaba en su poder el licenciado Agustín de Aranda y Arisco, cura del pueblo de Guayacotla. Prosiguiendo con su testimonio, Suárez contó que en otra ocasión se encontró en la Ciudad de México al sacerdote Aranda, quien, supuestamente, guardaba los documentos referidos por Enríquez, y aprovechó la oportunidad para preguntar por ellos. El sacerdote aludido le contestó que no tenía ningún documento que probara la conversión y herejía de Cerón de Valdez, y reprendió el comportamiento de su colega (AGN, C, vol. 611, expediente 4, f. 2v).

Un segundo testigo, el español Juan Alonso de Peralta y Coria, dio en su declaración la misma historia vertida por Joseph de Suárez y precisó que ella le fue contada por el propio licenciado Enríquez Cantú, en una ocasión en que fue a visitarlo a su casa. Asimismo, informó que otras personas, como Luis de Medina y Juan Fernández de Río Frío, se acercaron para informarle que el dicho cura les había platicado "las mismas injurias que tiene referido..." (AGN, C, vol. 611, expediente 4, f. 6). Así, esta causa criminal nos permite observar la estrategia de una injuria exenta de todo sustrato de espontaneidad, factor fundamental en la intencionalidad injuriosa. Los denuestos no fueron pronunciados en mitad de una reyerta, sino desde hacía tiempo atrás y ante varias personas; incluso, el injuriador visitó a los testigos para exponer su versión y, aún más, narró una historia en la que fundaba sus dichos, y la cual, si bien no fue corroborada, era parte sustancial en la trama injuriosa. De manera que la injuria referida fue difundida ampliamente, lo que probaba el dolo y premeditación con los que actuó el ofensor.

En la lectura de los discursos contenidos en las distintas demandas por injurias, el animo iniuriandi se destacaba, por parte del ofendido, mediante una serie de expresiones retóricas que tenían por objeto convencer al destinatario; en este caso, a los jueces que evaluaban la causa. El injuriado se presentaba como pacífico, "sin dar causa ni occasion alguna", al mismo tiempo que exaltaba la mala voluntad, 
el deseo de ofender del atacante. Las expresiones "y sin dar causa ni occasion alguna por no aver sido afecto al dicho rreo querrellado y mostrandosele su odio"; y, de forma más enfática, "...y en gran daño de su conciencia y con animo perverso y en ejecucion de su yrasible voluntad y con animo de ynjuriar al dicho mi parte y de migrar la buena fama y opinión", o, en palabras de Joseph de Suárez, testigo en el caso anterior, refiriéndose al ofensor, "le a tenido odio y mala voluntad al dicho don Martin ceron mostrandolo en todas sus acciones y conversaciones..." (AGN, C, vol. 611, expediente 4, f. 6v) pretendían persuadir al juez del ánimo perverso que movía a los injuriadores. De manera que la palabra injuriosa, en el escenario de una querella criminal, el ofendido la combatía con la exposición reiterada de la voluntad malsana de su atacante. Por su parte, este en ocasiones podía asumir esas categorías y explicar las razones que lo motivaron a la cólera y al enojo - presentando siempre las injurias como actos no premeditados, pues convenía al injuriador hacer valer que su agresión no había sido intencional-, o, como ocurría en la mayoría de los casos, negándolas.

Interpretar y asumir una injuria resultaba un acto eminentemente subjetivo que pocas huellas podía dejar: el expediente de una querella o la venganza. En realidad, son pocos los recursos con que cuenta el historiador para dilucidar la forma como se asumía una injuria. El derecho de la época escasamente abordó este tópico. En Las Partidas únicamente existe la expresión "tenerse por deshonrado", que fungía como el primer requisito para acudir a entablar una querella. Por su parte, en las causas criminales existen varias expresiones que señalan la condición de ofendido del injuriado: "Y sin haverles dado caussa me maltrataron de ofensa y de palabras...", "porque mi corazon ha tenido pesadumbre con sus malas palabras..." o "por las bexaciones de palabra que an resevido y esta resibiendo del dicho...". Eran estas fórmulas retóricas la evidencia del daño y el dolor que experimentaba un hombre ofendido mediante palabras injuriosas. No obstante, el mensaje de una injuria solía tornarse en opción, pues el ofendido podía perdonarla, asumirla o, como aconsejaba el caballero andaluz Diego de Valera, disimularla. "E sin dubda, señor, propio oficio de gran corazón [es] responderlas por honor, pero más prudencia es a tiempo disimularlas" (Valera t. CXVI 573).

El injuriado decidía según sus circunstancias; sin embargo, existían injurias cuya interpretación no podía ser otra más que la ofensa, y en ese escenario las consecuencias podían tornarse graves. El 3 de mayo de 1644, el Día de la Santa Cruz, en el pueblo de Misquiaguala, el indio Miguel Zuni "en publico con gran estruendo de palabras..." le dijo a su gobernador, Francisco Ximénez, que era un "cabrón cornudo" (AGN, C, vol. 54, expediente 4, f. 2), le dio de jalones y lo amenazó con matarlo, según el propio gobernador, solo por haberle solicitado unos ramos de rosas para aderezar la fiesta de la Santa Cruz. Iniciada la causa criminal, se presentó a declarar el alcalde ordinario del pueblo, Diego Martínez, quien infor- 
mó que la causa de la injuria contra "el dicho gobernador [fue] por aber entrado yncotinenti en su casa a buscar unas yndias para que truxesen unos ramos para la fiesta de la santa Cruz..." (AGN, C, vol. 54, expediente 4, f. 2). En su confesión, hecha a través de un intérprete, el ofensor no negó haberse "punineado" con el gobernador ni haberlo injuriado, pero aclaró que el motivo fue porque "el dicho gobernador entro incotinenti sin comedimento alguno dentro de la dicha mi casa [...] para buscar una hermana y otras indias..." (AGN, C, vol. 54, expediente 4, f. 2), para que llevaran los referidos ramos.

Es probable que la reacción de Zuni haya sido producto de una serie de rencores y corajes acumulados en contra del gobernador, pero el hecho que desencadenó el brete fue la acción que Zuni consideró como una afrenta. Al respecto, existen dos palabras que nos dan la clave en este altercado: incontinenti y sin comedimento. Ambos términos refieren, el primero, a la forma desenfrenada y apurada como Ximénez penetró a la casa de Zuni,y,el segundo, al modo poco amable como solicitó los ramos. Entrar a una morada de manera intempestiva es una acción poco cortés, y hacerlo para exigir —o sin comedimiento alguno, en palabras de Zuni- resultaba una franca grosería y un desafío para el individuo encargado de resguardar tal espacio, por antonomasia, el depósito adecuado para la conservación de la honra.

En otro caso más, Diego de Almonacir Salazar, notario y ayudante del secretario del Tribunal del Santo Oficio, Joseph de Rivera, se querelló criminalmente contra Martín Lussio, receptor de la Real Audiencia, porque el mediodía del domingo 22 de febrero de 1640 entró a su casa "con animo descompuesto y demudado y sin llamar [a nadie]", llegó hasta el comedor de la vivienda, donde se topó con el padre del querellante, y le exigió le pagase dieciséis pesos y cinco tomines que se le debían. El padre reaccionó pidiéndole que saliera de la casa, y acto seguido desenvainó su espada. Lussio retrocedió, y aunque intentó sacar la suya se contuvo y salió pronunciando "graves domelas injuriosas" contra el ayudante del escribano y su padre. De inmediato, Almonacir Salazar acudió a levantar la causa, en la cual asentó que no resultaba poca cosa la forma como el receptor entró a su casa, pues ello implicaba "grave deshonra contra la dicha mi morada..." (AGN, I, vol. 79, expediente $8, f .6$ ), por lo que pedía un ejemplar castigo para el ejecutor de tal despropósito.

En los dos casos, las injurias proferidas eran demasiado graves como para que los ofendidos disimularan. Las asumieron como tales, pero reaccionaron de forma distinta. Mientras Zuni combatió con una injuria lo que consideró como una ofensa contra él y su familia, y quedó al final como injuriado, Almonacir Salazar optó por una querella criminal. El primero, un inferior dentro del esquema social imperante en la época, y, por tanto, según las prédicas morales, imposibilitado 
para responder la afrenta de un superior, lo hizo con otra, y probó de esa forma el coraje que le produjo la agresión a su valía personal. En cambio, el segundo, más cauto, optó por defender su honra, maltrecha por un individuo no tan distante socialmente de él, en la arena del derecho, y demostró con ello que una injuria, más que un concepto, era un sentimiento, una convicción; de ahí la necesidad de llevarla hasta sus últimas consecuencias.

El moderno concepto de privacidad era prácticamente inexistente para la mayoría de los habitantes de los pueblos y ciudades novohispanas del siglo XVII, pues la mayor parte del tiempo sus puertas y ventanas permanecían abiertas y realizaban buena parte de sus actividades cotidianas en pasillos, corredores y patios, así como en las plazas y calles. Esa cercanía entre unos y otros proporcionaba información del prójimo y el derecho a hablar de él. En los procesos judiciales, la fórmula retórica expresada por los testigos "de mucho tiempo a esta parte conoze a..." resultaba significativa al respecto. Por estas razones, los vecinos fácilmente tendían a erigirse en elementos testimoniales en una causa por injurias, ya que casi nada podía pasarles inadvertido: discusiones conyugales, amores clandestinos, inquilinos ruidosos y, por supuesto, riñas e injurias eran vistas y oídas sin mayores esfuerzos (AGN, I, vol. 79, expediente 8, f. 6).

Los individuos presentes en una injuria tenían dos papeles que desempeñar: como testigos y como público en el teatro de la injuria. Como testigos tenían la función de relatar lo que habían visto (o lo que decían haber visto), y con ello constituían la "verdad" del hecho. Como público, las escenas de injuria eran una forma de teatralidad, y, por tanto, dependían de la mirada de unos espectadores que postulaban y creaban un espacio donde los protagonistas de la injuria desplegaban una "actuación social".

En el seno de una querella criminal por injurias, los testigos, en el momento de su declaración, alcanzaban a desempeñar un papel de primer orden, por dos razones: representaban lo sucedido a partir de lo que habían visto y oído, y porque todo testimonio estaba cargado de dignidad, en la medida en que ser testigo era un privilegio. Por ello, en la jura que precedía a la declaración debían comprometerse a decir la verdad, sin agregarle mentiras, sin modificarla bajo ningún pretexto, ni por rencor ni odio, para reconstruir efectivamente la trama acaecida ${ }^{3}$.

El juramento y sus fórmulas retóricas “...fue recibido juramento en forma de derecho so cargo del cual prometió de decir verdad”, o “....recibido juramento que los hizo por Dios nuestro señor y una señal de la Sancta Cruz en forma prometió de decir verdad" constituían las expresiones de un acto sagrado tendiente a certificar la veracidad de los testimonios dados. Jurar en falso era un grave pecado de perjurio, al mismo tiempo que un delito, pues atentaba contra la majestad de Dios, contra las instituciones de justicia real, contra toda la República y, por supuesto, contra el prójimo. Así, era un compromiso religioso a la vez que judicial (Cfr. Noriega 66). 
El 30 de noviembre de 1635 el barbero Alonso Gutiérrez Hidalgo se presentó ante el Juez Provisor de la Catedral, doctor Pedro de Barrientos Lomelín, para querellarse criminalmente contra el presbítero del Arzobispado de México, Diego González de Elías, porque el mediodía del miércoles 29 de noviembre de 1635 aquél entró a su casa, "y sin haber dado causa" profirió contra él y su mujer, de nombre Teresa, "malas palabras de infamia y deshonor...", y, no contento con ello, lo hirió en el rostro cortándole "cuero y carne..." (AGN, C, vol. 703, expediente $1, \mathrm{f} .3 \mathrm{v}$ ). Abierto el proceso criminal, se presentaron a declarar ocho testigos. Entre ellos destaca el testimonio de Diego López de Uriarte, por ser el más detallado y porque declaró haber estado cercano a los hechos. De calidad española, estudiante de Gramática en la Universidad y vecino de Gutiérrez en la Calle de la Acequia, expresó que el mediodía del 29 de noviembre acudió a la casa del barbero para que lo afeitara, pero no lo encontró; en cambio, halló al padre González de Elías, quien esperaba al injuriado. Justo cuando el testigo se disponía a salir, llegó Alonso y preguntó al presbítero el motivo de su visita, y este le respondió injuriándolo a él de "cabrón cornudo y a la dicha su mujer una gran puta..." y le reclamó "que como hablaba mal de las mujeres, y que no se metiera con ellas", a lo cual el barbero le respondió: "señor licenciado que mujeres me dice..." (AGN, C, vol. 703, expediente 1, f. 3v). Acto seguido, González de Elías le dio un puñetazo en el rostro, que lo derribó, y, posteriormente, con un leño que se encontraba cercano a la puerta, lo golpeó mientras lo seguía injuriando. La agresión concluyó, refiere nuestro testigo, cuando gente proveniente de la calle detuvo al sacerdote.

Otro de las testigos fue Luisa Núñez, de calidad española, viuda de Juan Bautista de Uriarte y tía del testigo anterior. En su testimonio asentó que ella no vio nada el día de la injuria, porque salió de su casa cuando todo había ocurrido. Pero en cambio refirió un altercado la tarde previa a los hechos injuriosos, cuando una mestiza de nombre María acudió al domicilio de Gutiérrez Hidalgo, para injuriarlo a él y a su esposa, Teresa, y luego amenazarlos con que los "...había de hacer matar a puñaladas, o a palos y que se lo habían de pagar". Asimismo, aseveró que "aunque no lo vio tiene por cierto" que la referida mestiza "tiene amistad y trato con el dicho licenciado llamado fulano Elías...". Concluyó su testimonio asegurando que la actuación del sacerdote fue a instancias de María; "referido tiene por cierto que el haber maltratado el dicho licenciado fulano Elías al dicho Alonso Gutiérrez fue por la dicha mestiza..." (AGN, C, vol. 703, expediente 1, f. 3v).

Este caso destaca por el número de testigos que se presentaron a declarar —ocho, cuando, regularmente, en los procesos por injuria existían tres o cuatro, o a lo sumo cinco-, porque todos conocían y tenían tratos con la pareja injuriada y porque todos los testimonios — con excepción de Luisa Núñez-, con algunas modificaciones en el vocabulario, dieron cuenta de la misma historia que la verti- 
da por el estudiante Diego López de Uriarte, aun cuando se suponía que él fue el único que presenció de cerca los hechos y los otros realizaban labores cotidianas en sus casas y trabajos, y acudieron ante el escándalo y el bullicio ${ }^{4}$. Elementos que hacen suponer que los testigos fueron aleccionados para que sus declaraciones favorecieran al querellante y probaran el dolo con el cual actuó el presbítero González de Elías.

En otro caso más, el 31 de agosto de 1700 el inquisidor Francisco de Deza y Ulloa levantó una sumaria criminal porque el día anterior el mulato Andrés de Briseño, su cochero, se vio involucrado en una injuria. Refiere el querellante que mientras Briseño circulaba sobre la Calle de San Lorenzo, al pasar por un charco de aguas sucias, solicitó a un hombre que se encontraba apoyado sobre la puerta de una panadería se retirara, para que no fuera ensuciado. Este hizo caso omiso, y de improvisto las mulas avanzaron y lo salpicaron. Ante esto, Juan Martín de Vargas, el referido individuo ensuciado, reaccionó gritándole a Briseño que era un "perro indio". El cochero, en palabras de su patrón, le reconvino para que no se alterara, pero el hombre entró a la panadería y salió de allí con un cuchillo en la mano, y con el cual hirió a su adversario (AGN, RFI, vol. 76, expediente 12, f. 4).

En las declaraciones de los involucrados, cada uno dio la versión que mejor le convino. Briseño declaró, convaleciente, que mientras solicitaba el permiso para cruzar el charco, "las mulas violentas se arrojaron y le salpicaron alguna cosa", por lo que Vargas reaccionó diciéndole "que era un perro indio y otras palabras injuriosas". El declarante asentó que se disculpó explicándole que "no había estando en sus manos" el control de las mulas, pero el injuriador "encendido más", entró a la casa y salió con un cuchillo de horqueta. En un intento por defenderse, el cochero tomó el azote para golpearlo, pero de improvisto otro individuo le arrojó una piedra y le golpeó el "lagartillo del brazo izquierdo" (AGN, RFI, vol. 76 , expediente 12 , f. 4).

Por su parte, los agresores —al final resultaron ser dos: los hermanos Juan Martín y Juan Antonio de Vargas, de oficio panaderos y de calidad española - declararon, el primero, que efectivamente se encontraba en el umbral de la panadería donde laboraba cuando el coche que conducía Briseño lo salpicó, pero, a diferencia de lo dicho por el injuriado, refirió que no le dijo nada: por el contrario, fue el propio cochero quien, tras avanzar unos pasos, lo injurió diciéndole que era un

4 Por ejemplo, Joana Saucedo, mestiza, soltera, con domicilio en la casa de doctor Antonio de Esquivel Castañeda, racionero de la Catedral, ubicada sobre la Calle de la Acequia y frontera a la casa de Gutiérrez, declaró que realizaba labores domésticas cuando escuchó el bullicio y se asomó por la puerta para saber lo que ocurría. Dio el mismo testimonio que Uriarte, cuando es claro que solo pudo ver y oír parte de lo acontecido (Noriega). 
"cabrón cornudo", a lo cual Vargas le respondió que "se fuese con dios que no le decía nada...", pero el mulato volvió a injuriarlo, y entonces nuestro declarante precisó que entró a la panadería en busca de su espada para castigar a cintarazos la insolencia de su ofensor; pero al no encontrarla, y viendo que aquel venía con el azote en la mano, decidió tomar un cuchillo y encararlo (AGN, RFI, vol. 76, expediente 12, f. 4 ).

El otro agresor, Juan Antonio de Vargas, hermano de este último, informó que dormía una siesta que interrumpió por el bullicio proveniente de la calle. Cuando salió encontró a su hermano discutiendo con el cochero y decidió acercarse para saber los motivos; pero, de improviso, Briseño levantó el azote para golpear a Juan Martín, por lo que "no pudiendo contenerse viendo la desvergüenza de dicho cochero siendo mulato atreverse a un español..." (AGN, RFI, vol. 76, expediente 12, f. 4), levantó una piedra del suelo y se la arrojó.

A la causa se presentaron a declarar tres testigos: Pedro López, Joseph de Osorio y Antonio Barreto. Este último informó que vio cuando el cochero le pidió al panadero que se apartara de la puerta para no ser ensuciando; sin embargo, de Vargas no lo hizo y resultó salpicado, por lo que reaccionó injuriando a Briseño llamándolo "perro indio" y reclamándole porque no había tenido cuidado al pasar. Briseño, que había avanzado algunos pasos con el coche, de improviso se detuvo y se apeó de él, para contestarle a de Vargas que era un "cabrón cornudo" y lo retó diciéndole "quiero valentías", mientras avanzaba amenazante hacia el panadero con el azote en la mano. Este reaccionó metiéndose a la panadería, y de ella salió empuñando un cuchillo, con el cual enfrentó a Briseño. Mientas esto ocurría, refiere el testigo, Juan Antonio de Vargas, el hermano de Juan Martín, apareció en escena levantando una piedra del suelo y arrojándosela al cochero (AGN, RFI, vol. 76, expediente 12, f. 4).

Eran los testigos, en estricto sentido, quienes con sus testimonios debían ayudar al juez de la causa a reconstruir la trama injuriosa, y por ello debían relatar no solo lo que habían visto y oído durante los hechos, sino también antes o después de ellos. Sin la participación de Luisa Núñez no habríamos comprendido, ni el juez tampoco, por qué al momento de golpear a Gutiérrez Hidalgo, el sacerdote Diego González de Elías le reclamaba "que como hablaba mal de las mujeres, y que no se metiera con ellas..."; y sin la declaración del testigo Antonio de Barreto tampoco habríamos tenido una panorámica más cierta de lo ocurrido entre el cochero Andrés de Briseño y el panadero Juan Martín de Vargas. De manera que estamos ante una de las funciones que debían desempeñar los testigos de una causa criminal: informar. Sin embargo, así como cumplían con este cometido, los testimonios también operaban como estrategias para ayudar o perjudicar a los implicados. En el caso de Gutiérrez Hidalgo, los testimonios más amplios y que 
ofrecen mayores datos provienen de personas de calidad española y, por tanto, según el Derecho de la época, eran testigos de calidad, y con ello se pretendía dar mayor credibilidad y legitimidad a la denuncia de Gutiérrez Hidalgo y probar su inocencia, y, al mismo tiempo, las intenciones infames que movieron a Diego González de Elías a actuar en la forma como lo hizo.

En toda comunidad al margen de las normas jurídicas y formales que la rigen existen ciertas normas concensuales sabidas y asumidas por sus miembros. En la sociedad novohispana del siglo XVII la tolerancia del adulterio masculino, la práctica de la prostitución y los pleitos en el interior del hogar y del taller eran algunos de esos fenómenos cuya lógica y reglas eran propias; sin embargo, no podían alejarse demasiado de aquellos valores socialmente aceptados, pues cuando esto ocurría se suscitaba un escándalo.

La noción de escándalo en el mundo novohispano se refería a un hecho en cuyo sustrato residía una valoración de índole moral. En el tratado de teología moral de fray Jaime de Corella, cuya circulación fue amplia en la Nueva España, se definía el escándalo como los hechos o palabras que podían causar la ruina del prójimo al inducir al mal ejemplo y dar la ocasión de pecar. No era necesario que tal acto fuera en sí malo: bastaba con el hecho de que tuviera esa apariencia (Corella 17). Era un pecado especialmente reprobado por Cristo en los Evangelios, y era de tal gravedad que se equiparaba con el homicidio, pues si el homicida privaba a su prójimo de la vida corporal, el escándalo mataba la vida espiritual de todo hombre, que era superior a aquella. Quien cometía pecado de escándalo quedaba excluido del reino de Dios (Ortega Noriega 74-75). De ahí que fuese elemento central de las políticas judiciales eclesiásticas y de la Corona y parte sustancial de la pastoral de la Iglesia. Y para que tales instituciones cumplieran su cometido, el de regular y vigilar el buen funcionamiento social, así como el de aplicar los correctivos necesarios para restablecer el orden, necesitaban que los miembros de la sociedad participaran como vigilantes de sus prójimos, para intervenir en aquellos actos que se tornaran escandalosos. Idealmente, se esperaba que las personas operaran los canales de comunicación institucionales y denunciaran a aquellos que tuvieran conductas subversivas del orden social. Instituciones como la Inquisición hicieron uso de este recurso en sus múltiples edictos para que los novohispanos denunciaran a aquellas personas sospechosas de herejía. Sin embargo, de forma regular, las personas que presenciaban o sabían de un hecho escandaloso no acudían a la denuncia ante la autoridad correspondiente, pues ello implicaba responsabilidades y tareas que casi nadie se veía dispuesto a asumir. Solo cuando eran requeridos por un juez se presentaban y manifestaban lo que sabían. En lugar de ello, los habitantes de la Nueva España se dedicaban a comentar con presteza, fruición y detalle lo que vieron y oyeron, a sopesar la gravedad de las circunstancias, a emitir su juicio y su condena personal; se estableció así una forma de comunicación social en la que los participantes expre- 
saban los valores de una comunidad, pero de una manera negativa, pues en el cotilleo callejero se resaltaba lo que parecía censurable de las situaciones y personas participantes en un escándalo. Las personas que chismeaban se ponían por encima de aquellas a quienes criticaban juzgándolas sin piedad, establecían comparaciones, desde una perspectiva moral, entre ellos y la persona de la cual hablaban, y se valoraban a sí mismas de manera positiva (Ortega Noriega 74-75). De forma que si bien no recurrían a la denuncia formal, como metáfora social, se erigían en una especie de policía mundana, que con sus comentarios juzgaba y sancionaba.

En un escenario social de estas características, la injuria, cuyo componente primordial era el escándalo, se convertía en un acto de muerte; de ahí que los injuriados consideraran que el escándalo fuese un elemento para considerar en el momento en que el juez dictara sentencia. Con ese sentido, Bárbara Rodríguez asentó en la causa que interpuso contra Isabel de Lara que las injurias prorrumpidas por esta fueron dichas "con estruendo de gritos y palabras", y causaron, con ello, un notable escándalo que repercutía en su reputación, créditos y buena fama; así como "en desdoro del honor de dicho mi marido..." (AGN, I, vol. 518, expediente 3, f. 1v). Asimismo, Dionisio de Merlo, vecino de la Ciudad de México, informó en la querella criminal que levantó contra los hermanos Juan y Agustín Pérez de Rivera, por haberlo injuriado de "judío marrano", el lugar de la injuria y los concurrentes a ella como agravantes del hecho injurioso: "en la plaza pública desta ciudad debajo de los portales a los doce del día martes pasado postrero de mayo en presencia de innumerables personas y con muchas voces de estruendo y grito..." (AGN, I, vol. 311, expediente 8, f. 2).

En el pensamiento y prácticas criminales de la monarquía española de los siglos XVI y XVII, la noción de pecado como concepto correlativo al delito fue patente, pues todo crimen involucraba, por necesidad, un pecado en la medida en que era una ofensa a Dios, al prójimo y a la armonía de la República. Tanto el pecado como el crimen rompían la concordia entre los hombres con Dios, y esta solo podía restablecerse mediante la expiación de la falta a través de la penitencia, el perdón y la reconciliación. Sin embargo, no se trataba de una identificación, pues no todo pecado era un delito; para que el primero adquiriese la condición del segundo era necesaria la manifestación de esa intención pecaminosa a través de comportamientos escandalosos (Trasloheros 93). La injuria era un pecado y un delito al mismo tiempo, pues era la exteriorización de una intención pecaminosa - el hurto de la honra - a través de un acto público y notable, y como tal constituyó una de las infracciones que las instituciones judiciales persiguieron: tanto las de la Corona como las eclesiásticas; estas últimas, en concordancia con la reforma de las costumbres impulsada por el Concilio de Trento.

Dado que en la injuria se robaba el bien preciado del honor, su castigo implicaba la restitución de ese bien a su legítimo poseedor, y suponía que las justicias de la 
Corona, al establecer una pena adecuada a ese desorden, estaban por encima de cualquier venganza privada. Así, el hurto del bien abstracto del honor alcanzaba reparación por parte del ofensor mediante sanciones de orden pecuniario o de naturaleza corporal. No obstante, muchos novohispanos que se veían involucrados en el delito de injuria buscaban evitar la imposición de las penas impuestas por las justicias reales, episcopales o inquisitoriales, mediante dos recursos: el perdón y posterior desistimiento del ofendido, o la solicitud al juez de la causa del sobreseimiento de la misma por falta de pruebas.

El primer recurso fue utilizado por el licenciado Manuel Gómez Mascorro en la querella criminal interpuesta en su contra por el minero de Taxco Juan de Chavarrieta, por haberlo injuriado llamándolo "borracho" y "cabrón cornudo" en una discusión por la propiedad de unos picos de minas. A instancias de su abogado, Joan de Rivera, el acusado le escribió al injuriado para solicitarle el perdón. $\mathrm{Al}$ respecto, es importante destacar que generalmente los ofensores buscaban el desistimiento por parte de su ofendido como último recurso. Este caso es representativo de tal condición. En la confesión que el acusado prestó el 28 de julio de 1639 , veinte días después de suscitados los hechos, pero también mes y medio antes de obtener el desistimiento, no hubo asomo de arrepentimiento de su actuación, sino, en cambio, varias justificaciones. Aceptó haber injuriado a Chavarrieta como respuesta a una injuria suya - lo llamó "judío marrano"- por haberlo amenazado con un cuchillo y empujado violentamente. Advirtió que su acusador era una persona acostumbrada a ocasionar "disgustos y pesadumbres" y añadió que su conducta había estado ajustada a "proceder y obras correctas" (Trasloheros 93). Sin embargo, tiempo después Gómez Mascorro se vio obligado a solicitar el perdón y a pasar por alto las acotaciones hechas por su ofendido en el desistimiento:

...hago de mi espontánea y agradable voluntad y no porque tenga miedo ni recelo de que no he de conseguir justicia porque tengo por cierto que si prosiguiera en la dicha causa vuestra Merced [refiriéndose al juez de la causa] me la hiciera como se ha visto en los principios de ella sino porque el dicho licenciado Manuel Gomes Mascorro a hecho petición de desistimiento... (Trasloheros 93).

Precisiones cuyo sentido era presumir su perdón, y que, en última instancia, eran una forma de hacer valer su precedencia.

El segundo recurso consistía en que el ofensor buscara el sobreseimiento de la causa a través de una solicitud al juez, en la cual aducía las razones que consideraba pertinentes. En la querella que presentó el regidor de la Ciudad de Valladolid, notario de secretos del Santo Oficio y familiar de él, Miguel de Almonacir, 
en contra del comerciante de la Ciudad de México y encomendero en la Ciudad de Valladolid, Gonzalo Yáñez, por haberlo injuriado llamándolo "perro y cabrón cornudo" al cobrarle una deuda. Este, cinco días después de haber sido detenido, presentó un escrito en el cual precisó que no era culpable de lo que se le acusaba, y, dado que tal cargo no implicaba pena capital ni corporal, solicitaba, previa fianza adjudicada, seguir el proceso criminal en libertad, pues en caso de continuar preso peligraban su crédito y buena fama, dadas sus actividades económicas (AGN, I, vol. 171, expediente 6, f. 7v). El juez de la causa le respondió en diez días y lo puso en libertad, siempre y cuando tuviera por cárcel su casa y no acudiera a otro lugar más que a su tienda y a la misa "por vía recta". Si no acataba esta provisión, se habría hecho acreedor a una multa de quinientos ducados. Yañez, no contento con esta disposición, continuó con sus diligencias, y dos días después consiguió que el juez lo dejara en total libertad conminándolo, junto con su ofendido, a que no volviesen a injuriarse, y se cerró de esa forma la causa criminal (AGN, I, vol. 171, expediente 6, f. 7v).

Durante los siglos XVI al XVIII todo delito implicaba concurrentemente ofensa a Dios, a la República y a la víctima, solo que en cada grupo de ellos se estimaba principal y dominante una de ellas. Así, había delitos en los que se atendía en primera instancia a su efecto dañino contra el "bien común". Se incluían aquí los delitos contra la vida, contra la propiedad y, por supuesto, contra la honra. Los autores de tales delitos eran públicamente peligrosos, perturbaban la paz y la convivencia con sus actos escandalosos, y contra ellos la sociedad tenía que defenderse. Por ello, Felipe II, en su Pragmática de 1567 (título XXV, libro XII, 416), estableció las penas que debían purgar aquellos que cometieran el delito de injuria. En ella se asentaba que la restitución de la honra robada en un acto injurioso implicaba, necesariamente, que el ofensor publicara, con la misma vehemencia con la que detractó, las disculpas correspondientes. Esta noción fue recogida en la fórmula retórica "desdecirse públicamente", la cual resultó en la práctica procesal parte constitutiva de la sanción establecida.

Con esa noción la consignó Bárbara Rodríguez en la causa criminal por injurias que promovió contra Isabel de Lara “...y que la dicha Isabel de Lara y Salamanca se desdiga con la misma publicidad para que yo mereciera el respeto que tengo y he tenido en esta república..." (AGN, I, vol. 518, expediente 3, f. 1v). Hizo lo mismo Dionisio de Merlo cuando instó al juez de la causa para que a sus injuriadores los mandara a condenar "con pena de desdecirse públicamente para reparar la dicha mi honra..." (AGN, I, vol. 311, expediente 8, f. 6). En el primer caso desconocemos si este requisito se cubrió, pues en el expediente no se encontró ningún dato al respecto; en cambio, en este último el querellante precisó: 
...en forma digo a V[uestra] S[eñoría] A sido servido mi petición y los susodichos han dicho y publicado por la ciudad y dicho a adeudos míos y personas que me tocan que en sus confesiones hay pesadumbre por haberme dicho las palabras de tanta injuria de que me he querellado... (AGN, I, vol. 311, expediente 8 , f. 6 )

Se cumplió con ello la restitución. Sin embargo, en ocasiones no bastaba la disculpa pública para finalizar una causa por injurias, sino que era necesaria la ejecución de una sentencia condenatoria por parte del juez de la causa. Así, en la querella que interpuso el gobernador Jiménez en contra de Miguel Zuni, el corregidor Francisco de Lora y Alvarado dispuso como sentencia condenatoria al acusado:

Dos años de destierro el uno preciso y el otro voluntario Cuatro leguas en contorno a esta jurisdicción. Y más le condeno en treinta pesos de oro común a que aplico por tercias partes a la Cámara de su Majestad y gastos de justicia y a tercio de estas casas reales y la dicha pena de destierro cumpla y no lo quebrante antes de ser cumplidos penas de doscientos azotes... (AGN, C, vol. 54 , expediente 4 , f. 8 )

Casi medio siglo después, Francisco Xavier Gómez de Cervantes, provisor y vicario oficial del Arzobispado de México, impuso como condena al licenciado Luis de Almaraz, en la querella criminal promovida en su contra por el doctor Andrés de Moreno, primero, una amonestación por su conducta deshonrosa; después lo convidó para que en el futuro evitara cometer delitos, excesos y riñas con persona alguna; posteriormente le solicitó no portar armas de ningún tipo, ni ofensivas ni defensivas, y lo llamó a guardar la compostura, modestia y virtud correspondientes a su estado religioso, y, finalmente, la pena mayor consistió en:

Un año de destierro de esta ciudad veinte leguas [alrededor] della los seis meses precisos y los seis voluntarios que guarde y observe sin quebrantarlo pena de que lo cumplirá doblado remitiendo testimonio dentro de veinte días a partir de notificada esta sentencia... (AGN, RFI, vol. 705, expediente 38, f. 32).

Con la advertencia, además, de que si no cumplía con estas disposiciones se le excomulgaría y se le remitiría a algún presidio por un tiempo conveniente.

Por su parte, el inquisidor Francisco de Deza y Ulloa, por las injurias proferidas a su cochero, dictó que los injuriadores, los españoles Juan Martín y Juan Antonio de Vargas, fueran "reprehendidos advertidos y conminados para que so pena de excomunión y de cuatro años de destierro a las islas Filipinas no 
se atrevieren ni de obra ni de palabra al dicho cochero..." (AGN, RFI, vol. 76, expediente 12, f. 16).

En la ejecución de la sentencia por el delito de injuria entraba en juego una serie de circunstancias que el juez debía sopesar. Al respecto, las disposiciones enunciadas en la séptima Partida prácticamente impusieron jurisprudencia en todo el derecho procesal de la monarquía hispana, y aseveraban que las consideraciones debían ser: la condición social tanto del injuriante como del injuriado, el lugar donde se cometió el delito, el dolo y la premeditación, el escándalo y la publicidad del acto, la cuantía del yerro (refiriéndose a la importancia del daño causado), la riqueza o pobreza del ofensor y su edad (Alfonso X el Sabio 592).

Así, tanto en el primero como en el segundo de los casos las injurias perpetradas eran graves si se observa la calidad de los injuriados - un gobernador de indios y un importante funcionario eclesiástico_- En este último caso, la calidad del injuriador también resultó un elemento importante por considerar: se trató de un sacerdote que con su comportamiento atentó contra su propio estado. Por otra parte, el lugar y las circunstancias de la injuria también eran agravantes. Mientras que el primero fue en mitad de una ceremonia religiosa importante, el otro ocurrió dentro de la casa del injuriado. El tercer caso era distinto, pues el agredido era un "inferior social", un mulato de oficio cochero, y los agresores, personas de calidad española; y aun cuando aquel pertenecía a la servidumbre de un hombre honorable, el inquisidor que coincidentemente llevó la causa —o quizás también por ello- optó por una reconvención a los injuriadores y la advertencia de que si volvían a cometer tales injurias — tal vez como prevención a posibles represalias_- el destierro sería la pena por pagar.

Es importante destacar que la mayoría de las sentencias que encontramos por delitos de injuria seguían un patrón similar al del último caso, pues generalmente concluían con una amonestación o una infracción pecuniaria leve a los injuriadores, y solo en casos considerados como graves se recurría a una pena mayor. En estas circunstancias, la sentencia seguía una dinámica semejante a la analizada por el historiador Jorge Trasloheros (96) para los delitos perseguidos por las justicias eclesiásticas. En principio, al reo se le dictaba un severo castigo ajeno a las penas de sangre, e inmediatamente después se precisaba que la sanción sería aplicada de manera parcial, bajo la advertencia de ejecutarla en su totalidad si el sentenciado no corregía su conducta delictiva. Así, a Almaraz, después de las reconvenciones hechas por su deplorable conducta, se le impuso la pena de un año de destierro a 20 leguas de la ciudad de México y — aquí, lo antes referido- "della los seis meses precisos y los seis voluntarios que guarde y observe sin quebrantarlo pena de que lo cumplirá doblado..." (AGN, RFI, vol. 705, expediente 38, f. 14). En el caso de Miguel Zuni existen algunas diferencias derivadas de su condición social, pues el tiempo de destierro fue mayor: dos años, de los cuales el primero era obli- 
gatorio y el siguiente, voluntario; si no los hubiera cumplido, habría sido azotado, lo cual implicaba un castigo corporal, además de la consiguiente pena pecuniaria. Estos elementos eran inexistentes en la sentencia de Almaraz, dada su condición de sacerdote. No obstante, es importante señalar que en ambos casos destaca la clemencia hacia el ofensor. Esto puede explicarse porque la justicia de la época, que, en última instancia, emanaba de la voluntad del soberano y la representaba, actuaba como un padre clemente, al mismo tiempo que justo y diligente frente a sus súbditos; de ahí que la amonestación y la reconvención fueran los recursos más socorridos en las penas impuestas por los delitos de injuria.

Sin embargo, la reconciliación entre injuriado e injuriador era el más caro objetivo de las justicias de reales, así como el de todo el discurso moral en torno a la injuria. Por eso, las palabras que expresó el mulato Vicente Francisco Pardo respecto a su injuriador, el inquisidor Diego de Vela, quien previamente le había solicitado su perdón: "y digo que como soy cristiano y porque Dios me perdone mis pecados lo perdono y me desisto y aparto de la dicha querella para por razón della no demandar cosa alguna..." (AGN, I, vol. 75, expediente 3, f. 22v). Asimismo, cuando Dionisio de Merlo asentó estar satisfecho con las excusas presentadas por sus injuriadores y, por consiguiente, desistió de la querella (AGN, I, vol. 311, expediente 8, f. 30), y cuando el juez de comisión en la causa criminal por injurias entablada por el minero Martín de Chavarrieta en contra del licenciado Manuel Gómez Mascorro, notificó "haber encontrado tratos de restitución entre las dichas partes..." (AGN, T, vol. 2778, expediente 1, f. 18). El aparato de justicia de la Corona estaba funcionando, pues mediante la expiación de la falta, el perdón y, finalmente, la reconciliación, se restablecían la armonía social y el orden moral, fines últimos del sistema jurídico de la monarquía española. 
de la histaria

\section{Bibliografía}

\section{Fuentes primarias}

Archivo General de la Nación, México (AGN)

Criminal (C)

Inquisición (I)

Real Fisco de la Inquisición (RFI)

Tierras (T)

Corella, Jaime de. Suma de theología moral. Madrid: Imprenta de Manuel Román, 1736.

\section{Fuentes secundarias}

Alfonso X el Sabio. Las siete partidas del Rey don Alfonso el Sabio. Cotejadas con varios códices antiguos por la Real Academia de la Historia. T 1-3. Madrid: Imprenta Real, 1807.

Burke, Peter. Hablar y callar. Funciones del lenguaje a través de la historia. Barcelona: Gedisa, 1996.

---. La cultura popular en la Europa Moderna. Madrid: Alianza Editorial, 2001.

Balandier, Georges. Antropología política. Trad. de Melitón Bustamante. $2^{\mathrm{a}}$ ed. Barcelona: Península, 1976.

Covarrubias Orozco, Sebastián de. Tesoro de la lengua castellana o española compuesta por el licenciado Don Sebastián de Covarrubias Horozco, capellan de su Magestad, Maestrescuela, y canonigo de la Santa Iglesia de Cuenca, y Consultor del Santo Oficio de la Inquisición, Madrid: Turner, 1984.

English Martin, Cheryl. "Popular Speech and Social Order in Northern Mexico, 1650-1830" Comparative Studies in Society and History: An Internacional Quarterly 32.2 (1990): 306-324.

Farge, Arlette. "Familias: El honor y el secreto". Historia de la vida privada: Del Renacimiento a la Ilustración. Aries, Philippe y Duby, Georges, dirs. Madrid: Taurus, 1989. 
Garrioch, David. "Verbal Insults in Eighteen-Century in Paris". The Social History of Languaje. Burke, Peter y Porter, Roy, eds. Cambridge: Cambridge University Press, 1987.

Ginzburg, Carlo. El queso y los gusanos: El cosmos según un molinero del siglo XVI. Barcelona: Muchnik, 1997.

--- "Indicios: Raíces de un paradigma de inferencias indiciales". Mitos, emblemas, indicios: Morfología e historia. Barcelona: Gedisa, 1999.

González, María del Refugio y Lozano, Teresa. "El alcalde mayor o el corregidor como jueces". Revista de la Facultad de Derecho de México. 35. 142, 143 y 144 (1985): 565-580.

--- "La administración de justicia". El gobierno provincial en la Nueva España. Woodrow Borah, coord. México: Instituto de Investigaciones Históricas-Universidad Nacional Autónoma de México 1985.

Lipsept-Rivera, Sonya. "Los insultos en la Nueva España en el siglo XVIII". Historia de la vida cotidiana en México. T. 3. El siglo XVIII: entre tradición y cambio. Pilar Gonzalbo Aizpuru, coord. México: El Colegio de México-Fondo de Cultura Económica, 2005. 473-500.

Mercado, Tomás de. Suma de tratos y contratos. Madrid: Instituto de Estudios Fiscales, Ministerio de Economía y Hacienda, 1977.

Millán, Antonio. "Los insultos 2008". 28 de mayo de 2008. <http://jamillan.com/ insultos/index.htm>.

Novísima Recopilación de las leyes de España: dividida en XII Libros, en que se Reforma la Recopilación Publicada por el Señor Felipe II, en el año 1567, reimpresa últimamente en el de 1775: Y se incorporan las pragmaticas, cedulas, decretos, ordenes y resoluciones reales, y otras providencias no recopiladas, y expedidas hasta el de 1804. T 1-5. Madrid. 1805.

Ortega Noriega, Sergio "El discurso moral acerca de la comunicación y su aplicación en la Nueva España". Senderos de palabras y silencios. Formas de comunicación en la Nueva España. México: Instituto Nacional de Antropología e Historia, 2000. 
Patlagean, Evelyne. "L'Histoire de l'imaginaire". La Nouvelle Histoire. Le Goff, Jacques; Chartier, Roger y Ravel, Jacques dirs. París: CEPL.1988.

Tomás y Valiente, Francisco. El Derecho penal de la monarquía absoluta (Siglos XVI, XVII y XVIII). Madrid: Tecnos, 1992.

Trasloheros Hernández, Jorge. Justicia y sociedad en la Nueva España: La Audiencia del Arzobispado de México (1528-1668). México: Porrúa; Universidad Iberoamericana de México, 2000.

Valera, Diego de. "Espejo de Verdadera nobleza". Desde la formación del lenguaje hasta nuestros días: Prosistas castellanos del siglo XV. T. 66. Madrid: Atlas, 1959.

Villafuerte García, Lourdes. "Lo malo no es el pecado sino el escándalo: Un caso de adulterio en la Ciudad de México". Senderos de palabras y silencios, Formas de comunicación en la Nueva España. México: Instituto Nacional de Antropología e Historia, 2000.

Fecha de recepción: 29 de mayo de 2008

Fecha de aprobación: 25 de septiembre de 2008 